\title{
Comparative study of corrosion in galvanized steel and different aluminum alloys
}

\author{
F. L. Xavier ${ }^{1}$ \\ F. P. Pinheiro ${ }^{2}$
}

\section{Abstract}

This academic work is a comparative about corrosion of galvanized steel and aluminum alloys, to determine their performances in different corrosive media with aim of to direct their applications. The parameters of corrosion rate, corrosion potential, potential for formation of pits and polarization resistance were obtained through of Electrochemical corrosion techniques, like: cyclic potentiodynamic polarization, electrochemical impedance spectroscopy, combined with corrosive media based on chloride and ammonia, used for industrial general cleaning. The aluminum alloys, 3105, 6082, and anodized 6082, presented more resistant than galvanized steel for the tests. Among the aluminum alloys, the anodized was more efficient than others, being indicated for applications that require mechanical resistance and aesthetics.

Keywords: Corrosion; Aluminum; Galvanized steel; Anodized Aluminium.

\section{Introduction}

\subsection{Overview}

The search for new technologies involving materials with longer life time, easy recyclability and affordable, boosted aluminum insert in construction, both

1 Technology and Development of New Products and Processes, Votorantim Alumínio, Alumínio, São Paulo, Brasil.

2 Technology and Development of New Products and Processes, Votorantim Alumínio, Alumínio, São Paulo, Brasil. 
for aesthetic purposes and for structural purposes, as it can be remelted without limits for his return to the production cycle.

\subsection{Corrosion control}

The metal corrosion is a process of gradual transformation to a metallic material or alloy may suffer due to their chemical or electrochemical interaction due to exposure to a particular environment resulting in more or less serious and widespread degradation of material - which causes economic losses and losses related to the lack of security.

The corrosion tests are gaining more space in the applications in order to prevent corrosion of metallic materials and developing economically viable and safe ways

Some of these assays, focus on the accelerated playback of the corrosion effect in a short time space, for example 24 hours or less with the premise of the used test conditions ensure the representation of a long-time use or service material (for example 1 year). [2]

\subsection{Passivation of aluminum}

The aluminum is corroded in alkaline and acid, whereas in the $\mathrm{pH}$ range between 4.0 and 8.5 , natural environments, occurs passivation of the aluminum oxide film $\left(\mathrm{Al}_{2} \mathrm{O}_{3}\right)$ filler and very sturdy, formed in its surface that protects against corrosion. Outside this $\mathrm{pH}$ range the dissolution of aluminum, corrosion, is favored thermodynamically. [3].

\subsection{Potentiodynamic cyclic polarization}

The potentiodynamic polarization is an electrochemical technique for obtaining polarization curves and provides the potential for continuous scanning, beginning on corrosion potential (the one that is established when the immersion of the material in solution, also called potential stabilized open circuit) potential or cathode dominated (more negative reactions that the corrosion potential), raising the potential at a constant scan rate. The scan rate, solution composition, the above immersion time, and the potential scanning range, beyond the test temperature, may influence the shape of the polarization curves.

A cyclic polarization curve the occurrence of pitting generates a large increase in current density, and the electrochemical potential where it occurs is called pitting potential. The more positive the more protection potential is the resistance of the material forming the pits. The pitting potential, Ep, is the strength of the 
material at the beginning of the formation of pits; when pits start and begin to grow, the current density increases rapidly. Reached the reversal current density (that the higher, indicating greater penetration or extension of the pit, or a greater number of formed pits) the potential scan is reversed, moving towards more negative potentials. At the moment the downward curve crosses the original curve has the so-called protection potential (EPP), which gets its name because below Epp is unlikely to break the passive film or a non-regeneration, being resistant material the occurrence of pits.

\subsection{Galvanization}

The electroplating or electroforming is the entire electroplating process in which metals are coated with more noble, usually to protect from corrosion or for aesthetic / decorative purposes as well, in case of damage, it is always easier to change the coater material than coated. The galvanizing process is the oldest and most widely used in the protection made of iron or steel objects. The process can be done by electroplating, as used for other metals, or alternatively without the passage of external electric current, by simple immersion in molten zinc [4].

\section{Materials and methods}

\subsection{Identification of metal samples}

Samples in dimensions: $3 \times 50 \times 100 \mathrm{~mm}$ of:

Galvanized steel; AA 3105; AA 6082 Anodized; - AA 6082.

The metals, were tested with the products, compositions and dilutions shown in Table 01.

The samples were submerged in the solution for a period of $24 \mathrm{~h}$

Table 1 Description of chemicals used for the corrosion tests:

\begin{tabular}{|l|l|l|c|}
\hline \multicolumn{1}{|c|}{ Product } & \multicolumn{1}{|c|}{ Composition } & \multicolumn{1}{|c|}{ Dilution } & PH \\
\hline $\begin{array}{l}\text { San Tab } 90 \\
\text { (Hidroall ) }\end{array}$ & trichloroisocyanuric acid & $\begin{array}{l}0,5 \mathrm{~kg} \text { in } 1000 \mathrm{~L} \mathrm{of} \mathrm{water} \\
\text { água }\end{array}$ & $\mathbf{2 , 4}$ \\
\hline $\begin{array}{l}\text { AVT } 450 \\
\text { (Poly Sell) }\end{array}$ & $\begin{array}{l}\text { Glutaraldehyde (50\%) Ammonia } \\
\text { Quaternary (80\%) }\end{array}$ & 1L in $1000 \mathrm{~L} \mathrm{of} \mathrm{water}$ & $\mathbf{5 , 3}$ \\
\hline
\end{tabular}


Table 1 Description of chemicals used for the corrosion tests: (continuation)

\begin{tabular}{|l|l|l|l|}
\hline \multicolumn{1}{|c|}{ Product } & \multicolumn{1}{|c|}{ Composition } & Dilution & pH \\
\hline $\begin{array}{l}\text { QUATERMON } \\
\text { (Chemitec) }\end{array}$ & Quaternary ammonia $(12,5 \mathrm{~g} / 100 \mathrm{~mL}$ ) & $1 \mathrm{~L}$ in $1000 \mathrm{~L}$ of water & 5,7 \\
\hline $\begin{array}{l}\text { GERMON } 80 \\
\text { (Sanphar) }\end{array}$ & $\begin{array}{l}\text { The base DiQQuaternary } \\
\text { ammonium }\end{array}$ & $1 \mathrm{~L}$ in $4000 \mathrm{~L}$ of water & 6,3 \\
\hline
\end{tabular}

\subsection{Determination of corrosion rate (icorr)}

Corrosion rate $=M / n F \rho \times$ icorr

$\mathrm{M}=$ atomic weight metal

$\rho=$ density

$\mathrm{n}=$ load number that indicates the number of electrons involved in the dissolution reaction;

$\mathrm{F}=$ Faraday constant $(96,485 \mathrm{C} / \mathrm{mol})$.

The calculation of the corrosion rate requires the determination of the corrosion current. When the reaction mechanism for the corrosion reaction is known to corrosion currents can be calculated using the Tafel slopes of the curves.

Density of materials

AA $3105=2720 \mathrm{~kg} / \mathrm{m} 3$

AA $6082=2710 \mathrm{~kg} / \mathrm{m} 3$

AS 6082 Anodized $=2710 \mathrm{~kg} / \mathrm{m} 3$ [5].

Galvanized steel $=7140 \mathrm{~kg} / \mathrm{m} 3$ (assuming the density of zinc as the protective layer was analyzed galvanized).

\subsection{Electrochemical tests}

Electrochemical Impedance Spectroscopy - EIS

To compare the performance of different metals in differents aggressive media was used the technique of electrochemical impedance spectroscopy - EIS. The EIS technique allows for system parameters such as the polarization resistance, Rp. The higher the polarization resistance, the higher the resistance to metal corrosion. This was one of the parameters used for comparative analysis of metals [6].

The EIS measures are generally analyzed using an equivalent circuit model. Most of the circuit elements in the model are common electrical components such as resistors and capacitors. To be useful, the elements in the template should have a physics-based electrochemical system. The models used for data analysis are presented in the results. 
For Potential analysis of open loop, cyclic polarization curves and electrochemical impedance spectroscopy, were performed using potentiostat / galvanostat METROHM brand.

\subsection{OCP analysis and EIS}

For performance benchmarking in relation to corrosion were used electrochemical techniques of open circuit potential monitoring (OCP) and electrochemical impedance spectroscopy (EIS).

The products were chosen since they are used daily in maintaining of constructions agriculture / agropepecuários. The studies were utilized to develop these structures totally composed of aluminum.

In the EIS analysis are used three electrodes: the reference electrode (Ag / $\mathrm{AgCl}$ in $\mathrm{KCl} 3.6 \mathrm{~mol} / \mathrm{L}$ ), working electrode (sample) and the counter electrode (platinum grade) to measure the current passing resistance electric.

the electrode contact area for OCP analysis was $37,5 \mathrm{~mm} 2$.

The measurements were performed at room temperature $\left(23^{\circ} \mathrm{C} \pm 1^{\circ} \mathrm{C}\right)$ and using a Multi-Potentiostat / Galvanostat (12 channels) of AUTOLAB.

Before the testings, the samples were cleaned using as a reference standard ASTM G1-03 (2011). The cleaning was done with detergent and water, rinsed with deionized water and dried with the aid of paper to absorb and degrease, using organic solvent (ethanol and acetone).

\section{Results and discussion}

\subsection{Open Circuit Potential Monitoring - OCP}

Monitoring the open circuit potential it was held for a period of $24 \mathrm{~h}$. After that time, the samples were analyzed by optical microscopy to verify the presence or absence of pitting. The results of the OCP measurements for different metals in different media were obtained through graphics and converted to table 2 .

Samples AA 6082 and AA 3105 had at least two peaks between time of $4 \mathrm{~h}$ and $10 \mathrm{~h}$ between $10 \mathrm{~h}$ and $16 \mathrm{~h}$ in medium San Tab. The presence of these peaks can be related to disruption of the barrier layer protective initially present in the base metal then the partial regeneration of this layer. 


\section{Graphics OCP Results}

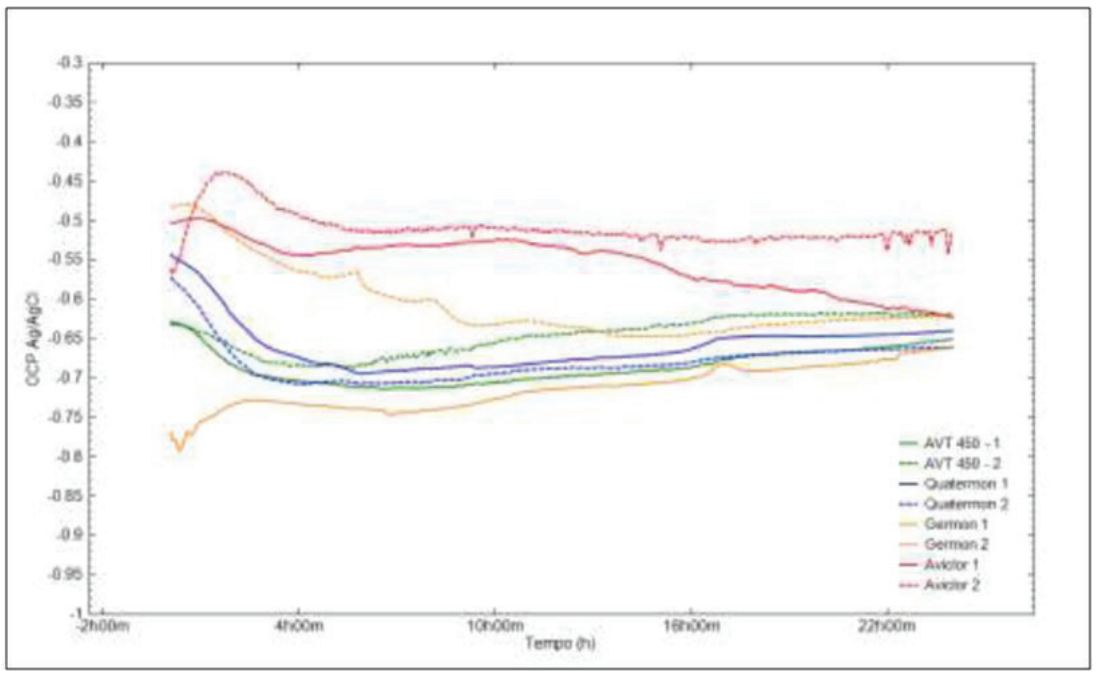

Figure 1 0pen circuit potential curve obtained in duplicate for AA 6082 anodized in different media Source: software AUTOLAB

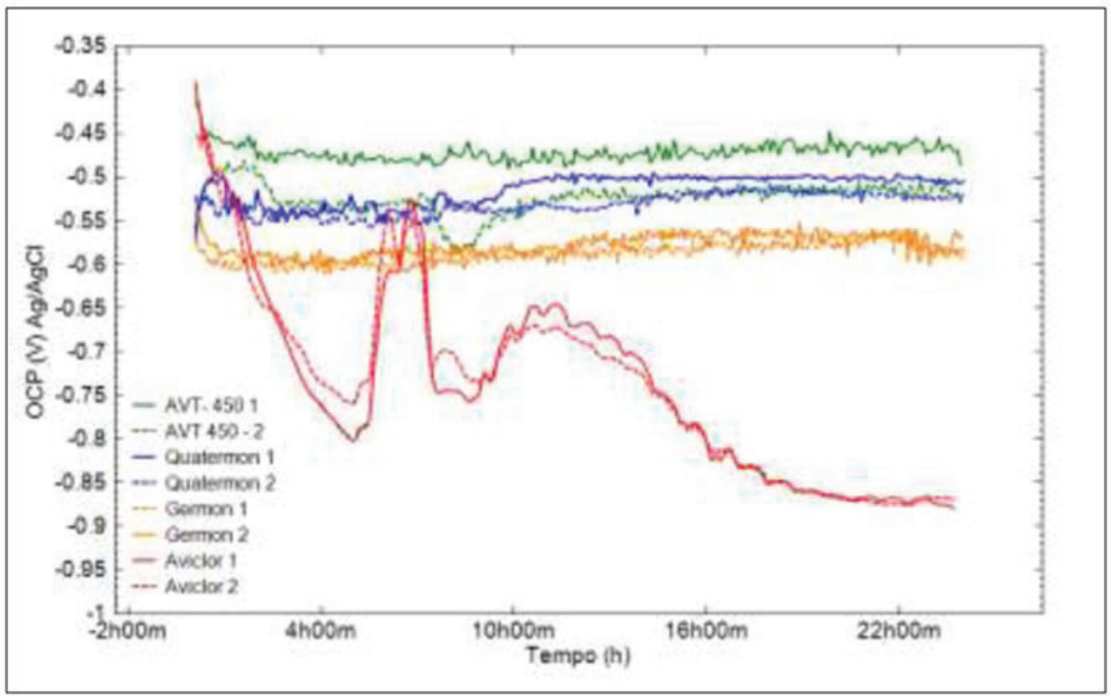

Figure 2 Open circuit potential curve obtained in duplicate for 3105 aluminum alloy in different media. Source: software AUTOLAB 


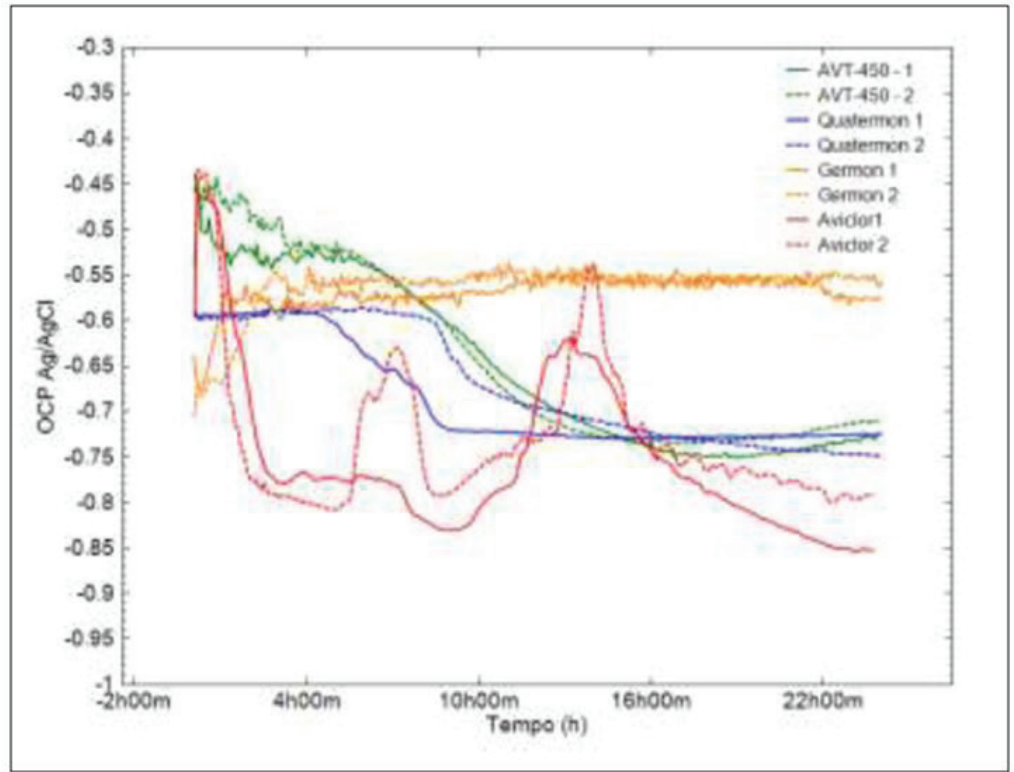

Figure 3 Open circuit potential curve obtained in duplicate for 6082 aluminum alloy in different media Source: software AUTOLAB

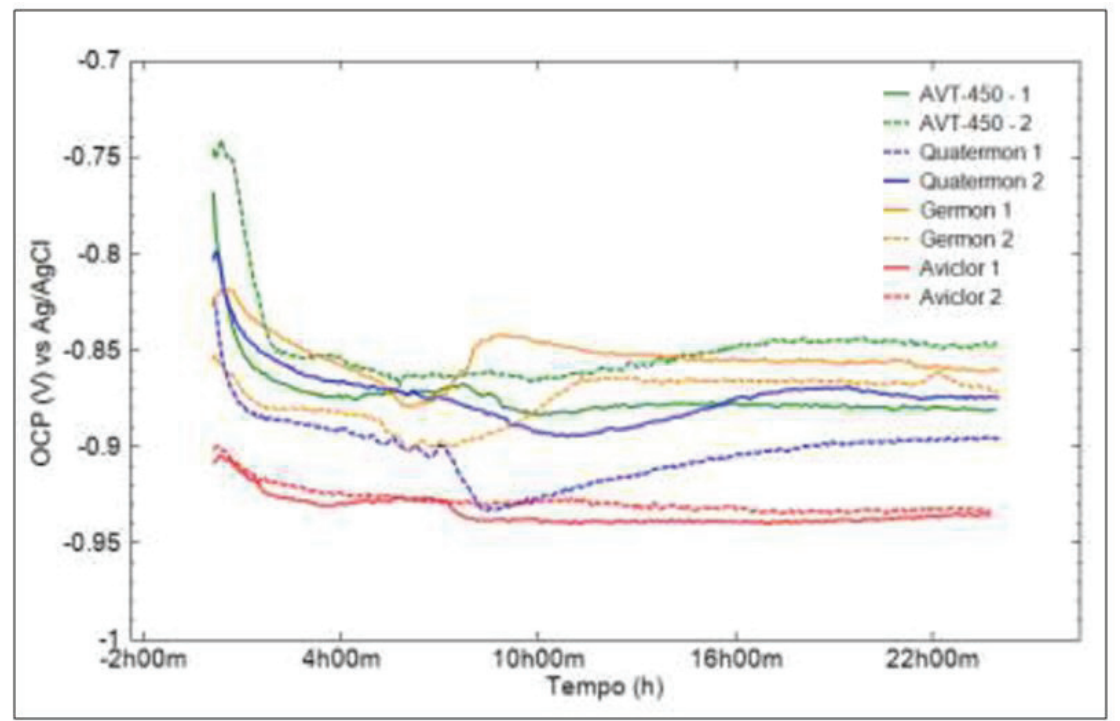

Figure 4 Open circuit potential curve obtained in duplicate for galvanized steel in different media.

Source: software AUTOLAB 
Table 2 Open Circuit Potential stabilized after 24 hours

\begin{tabular}{|l|l|l|l|l|}
\hline \multirow{2}{*}{ Material } & \multicolumn{4}{|c|}{ Open Circuit Potential OCP (V) } \\
\cline { 2 - 5 } & San Tab & AVT 450 & \multicolumn{1}{|c|}{$\begin{array}{c}\text { QUATER- } \\
\text { MON }\end{array}$} & GERMON 80 \\
\hline AA 6082 Anodized & $-0,560$ & $-0,630$ & $-0,645$ & $-0,640$ \\
\hline AA 3105 & $-0,875$ & $-0,510$ & $-0,510$ & $-0,570$ \\
\hline AA 6082 & $-0,820$ & $-0,715$ & $-0,735$ & $-0,555$ \\
\hline Galvanized Steel & $-0,893$ & $-0,860$ & $-0,880$ & $-0,845$ \\
\hline
\end{tabular}

\subsection{Corrosion rate}

The rate of corrosion and the corrosion current were obtained from Tafel curvess. The values of the Tafel curves of parameters after monitoring the OCP for 15 minutes on average.

The corrosion current density and polarization resistance $(\mathrm{Rp})$ was obtained from extrapolation of Tafel curve and the corrosion rate was calculated according to the formula mentioned in item 2.2

Table 3 Obtained parameter values of Extrapolation curves of straight Tafel

\begin{tabular}{|c|c|c|c|c|c|c|c|}
\hline & Media & $\begin{array}{c}\beta a \\
(\mathrm{mV} / \\
\text { dec) }\end{array}$ & $\begin{array}{c}\beta c \\
(\mathrm{mV} / \\
\mathrm{dec})\end{array}$ & $\begin{array}{l}\text { Ecorr } \\
(\mathrm{mV})\end{array}$ & $\begin{array}{l}\text { icorr } \\
(\boldsymbol{\mu A} / \\
\left.\mathbf{c m}^{2}\right)\end{array}$ & $\begin{array}{l}\text { Rp } \\
(\Omega)\end{array}$ & $\begin{array}{l}\text { Corrosion } \\
\text { Rate } \\
\text { (mm/ } \\
\text { year) }\end{array}$ \\
\hline \multirow{4}{*}{$\begin{array}{l}\text { AA } 6082 \\
\text { Anodized }\end{array}$} & GERMON & 30 & 100 & -734 & 0,000060 & $\begin{array}{l}18 x \\
10^{6}\end{array}$ & $6,7 \times 10^{-7}$ \\
\hline & QUATERMON & 25 & 108 & .754 & 0,000054 & $\begin{array}{l}18 x \\
10^{6}\end{array}$ & $6,0 \times 10^{-7}$ \\
\hline & AVT-450 & 42 & 90 & -668 & 0,000047 & $\begin{array}{l}28 x \\
10^{6}\end{array}$ & $5,3 \times 10^{-7}$ \\
\hline & SAN TAB & 59 & 105 & -513 & 0,000064 & $\begin{array}{l}28 x \\
10^{6}\end{array}$ & $7,1 \times 10^{-7}$ \\
\hline
\end{tabular}


Table 3 Obtained parameter values of Extrapolation curves of straight Tafel (continuation)

\begin{tabular}{|c|c|c|c|c|c|c|c|}
\hline & Media & $\begin{array}{c}\beta a \\
(\mathrm{mV} / \\
\mathrm{dec})\end{array}$ & $\begin{array}{c}\beta c \\
(\mathrm{mV} / \\
\mathrm{dec})\end{array}$ & $\begin{array}{l}\text { Ecorr } \\
(\mathrm{mV})\end{array}$ & $\begin{array}{l}\text { icorr } \\
(\mu \mathrm{A} / \\
\left.\mathrm{cm}^{2}\right)\end{array}$ & $\begin{array}{l}\mathbf{R p} \\
(\Omega)\end{array}$ & $\begin{array}{c}\text { Corrosion } \\
\text { Rate } \\
\text { (mm/ } \\
\text { year) }\end{array}$ \\
\hline \multirow{4}{*}{ AA 3105} & GERMON & 208 & 168 & -672 & 0,0028 & $\begin{array}{l}1,5 x \\
10^{6}\end{array}$ & $3,1 \times 10^{-5}$ \\
\hline & QUATERMON & 326 & 34 & -576 & 0,035 & $\begin{array}{l}42 x \\
10^{3}\end{array}$ & $3,8 \times 10^{-4}$ \\
\hline & AVT-450 & 573 & 30 & -530 & 0,094 & $\begin{array}{l}14 x \\
10^{3}\end{array}$ & $1,0 \times 10^{-3}$ \\
\hline & SAN TAB & 654 & 49 & -521 & 1,96 & $\begin{array}{l}1,1 x \\
10^{3}\end{array}$ & $21 \times 10^{-3}$ \\
\hline \multirow{4}{*}{ AA 6082} & GERMON & 167 & 205 & -598 & 0,0018 & $\begin{array}{l}2,4 x \\
10^{6}\end{array}$ & $1,9 \times 10^{-5}$ \\
\hline & QUATERMON & 470 & 30 & -501 & 0,091 & $\begin{array}{l}15 x \\
10^{3}\end{array}$ & $1,0 \times 10^{-3}$ \\
\hline & AVT-450 & 297 & 33 & -534 & 0,255 & $\begin{array}{l}51 x \\
10^{3}\end{array}$ & $2,9 \times 10^{-3}$ \\
\hline & SAN TAB & 677 & 33 & -508 & 1,15 & $\begin{array}{l}1,0 x \\
10^{3}\end{array}$ & $1,6 \times 10^{-2}$ \\
\hline \multirow{4}{*}{$\begin{array}{l}\text { Acto } \\
\text { Galvanized } \\
\text { Steel }\end{array}$} & GERMON & 255 & 45 & -809 & 3,01 & $\begin{array}{l}5,5 x \\
10^{3}\end{array}$ & $34 \times 10^{-3}$ \\
\hline & QUATERMON & 330 & 22 & -864 & 0,74 & $\begin{array}{l}1,3 x \\
10^{3}\end{array}$ & $11 \times 10^{-3}$ \\
\hline & AVT-450 & 383 & 92 & -883 & 0,112 & $\begin{array}{l}31 x \\
10^{3}\end{array}$ & $1,6 \times 10^{-3}$ \\
\hline & SAN TAB & 431 & 83 & -938 & 9,03 & $\begin{array}{l}0,37 \\
\times 10^{3}\end{array}$ & 13,5 \\
\hline
\end{tabular}

$\beta a$ and $\beta c$ are the Tafel constant; Ecorr - the corrosion potential; icorr - current corrosion, Rp - resistance polarization.

According to the results, the galvanized steel will deteriorate faster than other aluminum alloys, losing about $13.5 \mathrm{~mm}$ in thickness per year (in extreme exposure conditions). 


\subsection{Electrochemical Impedance Spectroscopy Measurements - EIS}

The EIS were carried out by applying the DC potential equal to the stable open circuit potential (after $24 \mathrm{~h}$ ). The applied voltage signal amplitude was 10 $\mathrm{mV}$ and the frequency range studied was between $100 \mathrm{KHz}$ to $1 \mathrm{~Hz}$. The settings of the EIS experimental curves were performed using equivalent circuits.

From the results of adjustments made using equivalent circuits, it created a table with polarization resistance values $\mathrm{Rp}$, which provides a measure of the resistance to metal corrosion in a given environment.

It is observed that the aluminum alloy had the highest values of polarization resistance, confirming the trend observed from $\mathrm{Rp}$ values obtained by Tafel curves. Again, the most aggressive medium was the San Tab. In all studied media, galvanized steel showed comparatively lower performance

Table 4 Values of Resistance Polarization obtained from the EIS data.

\begin{tabular}{|l|l|l|l|l|}
\hline \multicolumn{5}{|c|}{ Resistance Polarization - Rp (k $\boldsymbol{\Omega})$} \\
\hline & San Tab & AVT 450 & QUATERMON & GERMON \\
\hline AA 6082 Anodized & 115 & 97 & 92 & 124 \\
\hline AA 3105 & 3,58 & 71 & 91 & 34 \\
\hline AA 6082 & 1,74 & 83 & 148 & 57 \\
\hline Galvanized Steel & 0,49 & 8,53 & 0,84 & 1,9 \\
\hline
\end{tabular}
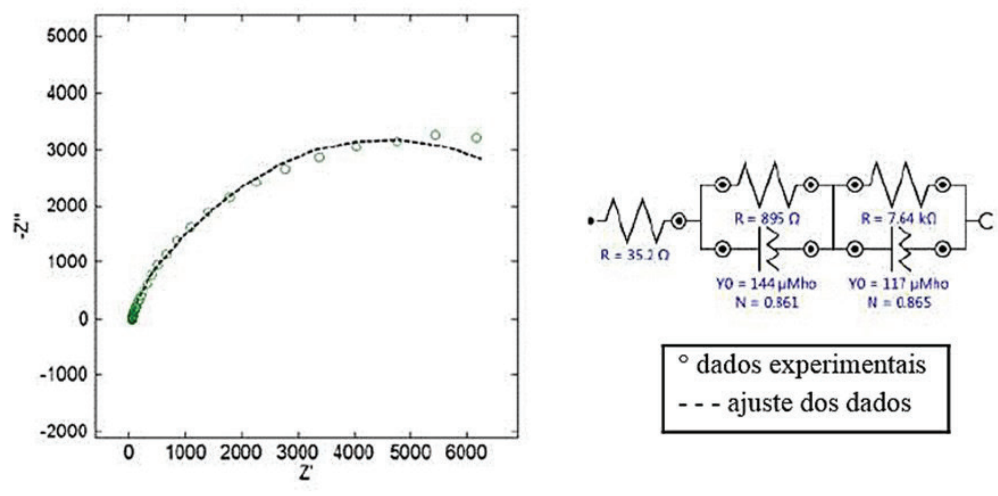

${ }^{\circ}$ dados experimentais
- - - ajuste dos dados

Figure 5 Illustrates the Nyquist diagram obtained for a galvanized steel sample AVT-450 medium and its corresponding equivalent electric circuit. Galvanized steel amid AVT - 450

Source: software AUTOLAB. 


\section{Conclusions}

Based on electrochemical results of OCP and EIS it was possible to classify the different metals tested with respect to resistance to corrosion front analyzed different ways. The samples of AA 6082 Anodized showed greater corrosion resistance, followed by AA 3105, after the AA 6082 and finally the Galvanized steel, which showed poor results for all tests in all medias.

In applications where aesthetics are required, the use of 6082 anodised aluminum alloy is the most suitable. Aluminum alloy 3105, is more susceptible to widespread corrosion than other aluminum alloys, so it is suitable for purposes where the aesthetic issue is not so relevant.

The galvanized steel due to low performance, is not suitable in applications requiring high corrosion resistance, because it has widespread corrosion easily.

\section{References}

[1] Portal Brasil. "PIB do Agronegócio cresceu 1,8\% em 2015”, acessado em 5 de março de 2016.

[2] GENTIL Vicente. CORROSÃO. São Paulo: LTC; 2010.

[3] GODARD Hugh P; JEPSON, W.B.; BOTHWELL M. R.; KANE, Robert L. THE CORROSION OF LIGHT METALS. Nova Iorque: The Electrochemical Society; 1967

[4] ABCEM - Associação Brasileira de Construção Mecânica: "O que é galvanização a fogo (zincagem por imersão a quente)", acessado em 12 de março de 2016. Disponível em: http://www.abcem.org.br/galvanize/galvanizacao-a-fogo-artigos-tecnicos.php

[5] ALTENPOHL. Dietrich G. ALUMINUM: TECHNOLOGY, APPLICATIONS AND ENVIRONMENT. Sexta edição. Washington: The Aluminum Association; 1998.

[6] SONG, Y. and Hung, P. Electrochemical Impedance Spectroscopy Analysis on Type III Anodized Aluminum 6061-T6 with Thermal Cycling. 2015 ANODIZING CONFERENCE, San Diego, California. Aluminum Anodizers Council. 
